\title{
Do University Presidents Make a Difference? A Strategic Leadership Theory of University Retrenchment
}

\section{ART BUDROS}

McMaster University

\section{ABSTRACT}

Although the general consensus is that university presidents do not make a difference, most research on this issue is atheoretical and perceptual in nature. Consequently, I draw on strategic leadership theory to examine whether observable experiences of presidents affected the adoption of retrenchment (early faculty retirement) plans among Ontario universities from 1989-90 to 1997-98. In doing so, I also advance strategic leadership theory by introducing novel measures of leaders' observable experiences and by testing their impact on an outcome (retrenchment) in a noncorporate setting. Since early faculty retirement plans have spread across universities, and since evidence indicates that they combine financial benefits and academic costs, their adoption represents a key structural change begging for explanation. Although the literature attributes the adoptions to uncontrollable forces, I report that presidents play a major role in the adoptions. Those who lack seats on corporate boards, who have non-business or non-economics backgrounds, who are male, and who are recruited externally adopt the plans at lower rates than their respective counterparts. The results portray presidents as exercising circumscribed agency, strategizing on the basis of their personal and professional experiences and making a difference even under inhospitable circumstances. 


\section{RÉSUMÉ}

Bien que tous s'accordent à dire que les présidents d'université ne font aucune différence, la plupart des recherches à ce sujet sont athéoriques et de nature perceptuelle. Je puise dans la théorie du leadership stratégique pour examiner si les pratiques observables des présidents affectent l'adoption des programmes de réduction (retraite anticipée du corps professoral) dans les universités ontariennes entre 1989-90 et 1997-98. De plus, en faisant cela, je présente la théorie du leadership stratégique en introduisant des mesures innovatrices des pratiques observables des présidents et en mesurant leur impact'sur les résultats des réductions dans un cadre non corporatif. Puisque les programmes de retraite anticipée du corps professoral se sont propagés à travers les universités, et puisque les preuves établissent un lien entre les gains financiers et les coûts académiques, leur adoption représente un changement structurel clé qui nécessite des explications. Bien que les ouvrages attribuent l'adoption des programmes à des mouvements incontrôlables, je rapporte que les présidents jouent un rôle primordial dans ces adoptions. Les présidents qui ne siègent pas à un conseil d'administration, ceux qui ne possèdent aucune expérience des affaires commerciales ou économiques, ceux qui sont des hommes ou ceux qui sont recrutés de l'extérieur adoptent le programme à un taux inférieur à leurs homologues respectifs. Les résultats présentent les présidents administrant des instruments déterminés par une stratégie basée sur leurs expériences personnelles et professionnelles même dans des circonstances inhospitalières.

Although the issue of whether university presidents make a difference has been debated for decades, most researchers (Birnbaum, 1989b; Cohen \& March, 1974; Dennison \& Gallagher, 1986; Sibley, 1993) conclude that presidential powers are circumscribed greatly. However, nearly all of the research lacks grounding in a formal theory (Birnbaum, 1989a) and relies on the perceptions of campus figures (Levin, 1992). Seeking more definitive conclusions about presidential power, I use strategic leadership theory (Boeker, 1997; Finkelstein \& Hambrick, 
1996; Hambrick \& Mason, 1984) to analyze whether observable experiences of presidents influenced the adoption of retrenchment (early faculty retirement) programs among Ontario universities from 1989-90 to 1997-98. Adoption of these programs has become common over the past decade (Gwyn, 1996; "Making the transition," 1992; Melchers, 1998; Peters, 1995; "Summary," 1993) and indications are that this activity has generated negative consequences, including larger and more impersonal classrooms, overworked faculty with low morale, and deteriorating academic quality ("Making large classes work," 1992; McGaw, 1993; "Tips and techniques," 1991). So the adoptions constitute a key structural change among universities that combines potential economic gains and educational losses, raising the provocative question: Are these adoptions affected by presidential orientations or are they driven by pressures beyond presidents' control, as the literature proposes (Gumport, 1993; Lorimer, 1993; Melchers, 1998; Neumann, 1995; Peters, 1995; Slaughter, 1993; "The thorny problem," 1990)? Addressing this question also provides an opportunity to advance strategic leadership theory, which emphasizes the relationship between three characteristics reflective of leaders' observable experiences - tenure, functional background, and formal education - and outcomes among corporations (Finkelstein \& Hambrick, 1996). Recognizing the need to expand the set of leader experiences and populations that have been explored, I introduce novel measures of leader experiences in explaining an outcome (retrenchment) in the educational sector.

In section I, I review the literature on presidential power, and in section II, I discuss the concept of retrenchment and its history among Ontario universities. In the next two sections, I present a strategic leadership theory of retrenchment and the methodology used to test the theory. Section V reports that presidents play a key role in the adoption of retrenchment schemes. Those who lack seats on corporate boards, who have non-business or non-economics backgrounds, who are male, and who are external appointments adopt early faculty retirement packages at lower rates than their respective counterparts. The results portray presidents as exercising circumscribed agency, making decisions on the basis of their personal and professional experiences and thus making a 
difference even under unfavorable conditions. In section VI, I conclude that tests of integrated theories in diverse contexts can enhance our understanding of the link among leaders, their organizations, and organizational outcomes.

\section{PRESIDENTIAL POWERS}

Organizational power refers to the ability to shape organizational outcomes despite resistance (Hardy 1996), and there are three positions on the power of the college or university president. The majority position is that presidential power is constrained by such internal forces as campus interest groups, faculty and trustee involvement in governance, and faculty collective bargaining, as well as by such external forces as public distrust of higher education, reduced government funding of postsecondary institutions, and state rules and regulations governing these institutions (Birnbaum, 1988; 1989b; Cameron, 1991; Chaffee, 1984; Cohen \& March, 1974; Corson, 1960; 1975; Dennison \& Gallagher, 1986; Fisher, 1984; Gray, 1998; Hodgkinson, 1971; Jencks \& Reisman, 1968; Kerr \& Gade, 1986; Levin, 1995; McGrath, 1971; Mortimer \& McConnel1, 1978; Neumann, 1989; Reisman, 1970; Schuster et al., 1994; Shapiro, 1998; Sibley, 1993; Stoke, 1959; Vaughan, 1986). For example, Dennison and Gallagher (1986: 195) view presidential power in Canadian postsecondary institutions as a "fluid and elusive thing," adding that anyone who tries to get a fix on power will find it "slipping away like sand in the face of storms and driving tides." Some scholars (Birnbaum, 1988; 1989b; Gray, 1998) caution against drawing easy conclusions about presidential discretion. Birnbaum (1988; 1989b), for one, did not find a link between presidential succession and institutional cultures, but recognizes that studies of other institutional outcomes could find otherwise. Constraint advocates (Birnbaum, 1988; Cameron, 1991; Dennison \& Gallagher, 1986; Fisher, 1984; Glenny et al., 1976; Jencks \& Reisman, 1968; Kerr \& Gade, 1986; McGrath, 1971; Neumann, 1989; Schuster et al., 1994; Vaughan, 1986) generally agree that presidential autonomy has been shrinking over time. For example, Kerr (1963: 32-3) laments that the 
day of the "Captain of Erudition" has been superseded by the day of the "Captain of the Bureaucracy," who sometimes is a "galley slave on his own ship."

Nearly always based on dated evidence and observations, one of the two minority positions is that presidents wield substantial power (Baldridge et al., 1980; Blau, 1973; Clark, 1973; Demerath et al., 1967; Gilley, Fulmer, \& Reithlingshoefer, 1986; Gross \& Grambsch, 1968; 1971). For example, Clark (1973) recounts how the founders of Antioch College in the 1860s, Reed College in the early 1900s, and Swarthmore in the 1860 s created "sagas" that enabled them to have an enduring impact on their institutions. The other minority position is that presidents are constrained in some ways but not in others (Levin, 1992; Neumann \& Bensimon, 1990). Levin (1992: 42) states that the president "both does and does not make a difference" in Canadian colleges. Presidents affect a college's culture and reputation but not its policies and programs regarding budgeting, educational planning, financial efficiency, and related matters. Such structures are thought to be determined by environmental forces beyond the president's control.

With few exceptions (Birnbaum, 1988; 1989b; Cohen \& March, 1974), research supporting the majority position (and the others) on presidential power shares two peculiarities. One is that studies have been atheoretical and have not been grounded explicitly in a formal theoretical framework (Birnbaum, 1989a). The other is that studies have been based on the perceptions of such campus figures as presidents (Levin, 1992). I address these theoretical and methodological peculiarities by drawing on strategic leadership theory (Boeker, 1997; Finkelstein \& Hambrick, 1996; Hambrick \& Mason, 1984) to explain whether the professional backgrounds and experiences of presidents affected the adoption of retrenchment (early faculty retirement) plans among Ontario universities from 1989-90 to 1997-98. Before turning to the theory, I discuss the concept of retrenchment and its history among Ontario universities. 


\section{RETRENCHMENT}

As defined here, university retrenchment refers to a set of policies an institution uses to cut its expenses in the face of environmental and organizational contingencies (Gates, 1997; Gumport, 1993; Hardy, 1996; Neumann, 1995; Rhoades, 1998; Slaughter, 1993). Retrenchment is goal-oriented or means-oriented, specific strategies are associated with each orientation, and there is tentative evidence on the effectiveness of each specific strategy (Chabotar \& Honan, 1990). The goal-oriented strategy redefines an institution's fundamental goals, occurs through the contraction of functions, and evidently is pursued more effectively by eliminating unprofitable programs than by decreasing athletic programs or community services. The means-oriented strategy entails devising improved means by which an institution can manage resources in pursuing its goals. Laying off faculty, decreasing faculty size, increasing budget control, or implementing energy conservation have been designated as more effective strategies than laying off administrative staff, decreasing campus maintenance, decreasing salaries, or decreasing student recruitment. Reducing faculty size especially is effective because faculty salaries and fringe benefits represent an institution's single largest expense, often exceeding fifty percent of the budget. Faculty retrenchment or the pursuit of expense cuts through the elimination of faculty thus has become a prominent retrenchment strategy (Chabotar \& Honan, 1990; Gates, 1997; Gumport, 1993; Hardy, 1996; Neumann, 1995; Rhoades, 1998; Slaughter, 1993).

Although faculty retrenchment attracted attention across Canada during the mid-to-late 1980 s, universities displayed a strong preference for cutting material (e.g., equipment) rather than more divisive nonmaterial (personnel) expenditures (Hardy, 1996; Renner, 1986; 1988; Skolnik, 1986; 1987; Skolnik \& Rowen, 1984). Reflecting the rarity of faculty reductions in Ontario, Table 1 (Series 1) shows that the total number of full-time (tenure-track and tenured) faculty in the province consistently rose during the 1980 s, with one trivial exception (1981-82 to 1982-83). Although universities have continued to cut material expenditures through closings of athletic programs, improvements in energy 
Table 1

Full-time faculty at Ontario Universities, 1989-90 to 1997-98

\begin{tabular}{ccc}
\hline Year & Series 1 & Series 2 \\
\hline $1979-80$ & 8,892 & 8,892 \\
$1980-81$ & 8,983 & 8,983 \\
$1981-82$ & 9,003 & 9,003 \\
$1982-83$ & 9,003 & 9,003 \\
$1983-84$ & 9,047 & 9,047 \\
$1984-85$ & 9,083 & 9,083 \\
$1985-86$ & 9,314 & 9,314 \\
$1986-87$ & 9,390 & 9,390 \\
$1987-88$ & 9,559 & 9,559 \\
$1988-89$ & 9,671 & 9,671 \\
$1989-90$ & 9,863 & 9,863 \\
$1990-91$ & 9,996 & 9,996 \\
$1991-92$ & 10,028 & 10,541 \\
$1992-93$ & 10,140 & 10,661 \\
$1993-94$ & 10,043 & 10,598 \\
$1994-95$ & 9,768 & 10,301 \\
$1995-96$ & 9,704 & 10,232 \\
$1996-97$ & 9,086 & 9,569 \\
$1997-98$ & 9,168 & 9,669
\end{tabular}

Source: Statistics Canada

Notes: Series 1: Nipissing University and Ryerson Polytechnic University excluded. Series 2: Nipissing University and Ryerson Polytechnic University included. 
efficiency, and other means ("Cuts hurt," 2000; "Making the transition," 1992; "University funding," 1991), interest in faculty retrenchment has grown as universities have recognized the potential cost savings available through decreases in compensation and personnel levels (Lorimer, 1993; "Our aging professoriate," 1989; "Social contract," 1993). The strict procedures for faculty layoffs have rendered such events virtually impossible (Cameron, 1991), pushing universities to explore such faculty reduction strategies as attrition through regular retirements, compensation freezes, and early retirement schemes (Lorimer, 1993; "Making the transition," 1992; "Social contract," 1993). Since early faculty retirement schemes can reduce large numbers of faculty quickly, with expectations of large savings in the future, they have become the retrenchment strategy of choice (Gwyn, 1996; "Making the transition," 1992; Melchers, 1998; Peters, 1995; "Summary," 1993).

Table 1 presents two statistical series: Series 1 shows the overall number of full-time (tenure-track and tenured) faculty at Ontario universities, excluding Nipissing University and Ryerson Polytechnic University; Series 2 includes data on Nipissing and Ryerson, which were established in 1993-94 and 1991-92, respectively. Both series show that the number of full-time faculty rose during the early $1990 \mathrm{~s}$, peaked during 1992-93, and declined during the mid 1990s before stabilizing during 1997-98. They also show that the number of faculty in the province has declined over 10\% since 1992-93. Although these declines could have been driven by multiple retrenchment strategies and other factors, information secured from the Ontario universities reveals that they have occurred overwhelmingly due to early retirements. This situation makes sense, since, with one exception, each Ontario university introduced an early faculty retirement program in the 1990 s, and each one contributed significantly to reductions in the university's overall faculty size. This means that these programs are linked to declining faculty size at the provincial and university levels.

I focus on early faculty retirement programs not only because they have become the dominant means of retrenching but also because their introduction has important ramifications. Cuts in material expenditures can leave universities with inadequate facilities and equipment, 
undermining the education process. But more worrisome are cuts in human expenditures achieved through early faculty retirement programs that generate overall reductions in the number of university faculty. These reductions require that fewer faculty (perhaps with inadequate facilities and equipment) transmit knowledge and skills to students, and the adverse effects of this situation purportedly include: fewer course offerings, larger and more impersonal classrooms, less student-professor contact, overworked faculty with low morale, and deteriorating academic quality ("Making large classes work," 1992; McGaw, 1993; "Tips and Techniques," 1991). So retrenched universities may well have difficulties cultivating intellectual mastery among students, continuing the search for knowledge, and serving their diverse communities. As a result, presidential influence on retrenchment decisions becomes a vital issue.

Since the literature stresses that the adoption of retrenchment (early faculty retirement) programs has been driven by uncontrollable pressures - especially, voters' criticisms of financial efficiency and leadership on campuses and the resulting efforts of government bodies to cut university funding (Gumport, 1993; Hardy, 1996; Lorimer, 1993; Melchers, 1998; Neumann, 1995; Peters, 1995; Slaughter, 1993; "The thorny problem," 1990) - these findings should support the majority position on presidential power: Knowledge about presidential characteristics should not help us to distinguish between universities with high versus low retrenchment rates because the presence of strong constraints has forced presidents with diverse characteristics to retrench. Findings revealing that presidents do matter - those with certain professional histories sponsor retrenchment and those with different histories oppose it - would challenge the majority position, portraying presidents as agents capable of influencing institutional functioning against long odds. Below, I develop a theory on why universities with one type of president should be less likely than ones with other types to retrench. 


\section{A STRATEGIC LEADERSHIP THEORY OF RETRENCHMENT}

\section{Overview}

The term, strategic leadership, refers to top managers who make choices that push an organization in one strategic direction or another. Accordingly, strategic leadership theory assumes that leaders shape organizations, focusing on the link between the psychological and social orientations of leaders and organizational outcomes (Bantel \& Jackson, 1989; Boeker, 1997; Finkelstein \& Hambrick, 1996; Hambrick \& Mason, 1984). With respect to leaders, attention centers on how chief executive officers (CEOs) and top management teams with responsibility for overall organizational management differ in terms of psychological and observable characteristics. The theory emphasizes such psychological attributes as cognitions and values, and personal and professional experiences embodied by such characteristics as tenure and functional background. With respect to organizational outcomes, attention centers on performance and on strategic and structural change. Specific outcomes of interest include CEO compensation and dismissal, diversification and divestitures, mergers and acquisitions, and profits and sales.

The logic of bounded rationality underlies the link between leaders' orientations and organizational outcomes. Typically overloaded with multiple, ambiguous, and even contradictory organizational and environmental stimuli, leaders develop a construed, simplified definition of the strategic situation using a three-step information filtering process. The first step is to establish a limited field of vision through exposure to a subset of all stimuli. The second involves selectively perceiving or noticing a portion of the stimuli in the field of vision. The third step is to engage in sense-making, interpreting or attaching meaning to stimuli. Leaders filter in different ways because they possess different psychological and social orientations. As a result, they differ systematically in their recognition and interpretation of strategic stimuli, their tolerance of ambiguity, their levels of aspiration, cognitive complexity, and political acumen, their beliefs about causation, and even their views of their mission and how urgent it is. So facing identical internal and external contingencies, leaders with different orientations should develop different 
definitions of the strategic situations and thus prefer different outcomes. And as these preferences are pursued, an organization becomes a reflection of its leaders.

Like the literature on presidential powers, strategic leadership theory posits that courses of action generally will be determined by environmental pressures, and not by leaders, when substantial constraints are present. But this position leaves room for constrained leaders to perceive, to create, and to pursue alternative actions, relying on their creativity and insight, persistence, political acumen, sheer will, and other personal qualities and experiences. This theory also suggests that leaders can make a difference by endorsing or thwarting change, and that the organizational effects of change can be functional or dysfunctional. I draw on the theory in considering whether knowledge about the divergent orientations of constrained presidents helps us to differentiate between retrenched and nonretrenched universities. If it does, then presidents matter in the sense that those with certain orientations can resist adopting a plan (retrenchment) with potential economic functions and academic dysfunctions, when facing strong pressures to do otherwise. I now identify these orientations by formulating the specific hypotheses to be tested.

\section{Specific Hypotheses}

There is considerable research on whether three background characteristics reflective of leaders' observable experiences - tenure, functional background, and formal education - influence outcomes in the corporate sector (Bantel \& Jackson, 1989; Boeker, 1997; Finkelstein \& Hambrick, 1996). Two key weaknesses in this research are the narrowness of the leader experiences and populations that have been studied (Finkelstein \& Hambrick, 1996). Recognizing the potential theoretical and empirical payoffs of supplementing these studies with ones that investigate different leader experiences in different industrial sectors, I consider whether six background characteristics of university presidents - tenure, age, academic background, successor type, corporate board experience, and gender - explain the adoption of retrenchment (early faculty retirement) packages among Ontario universities from 1989-90 to $1997-98$. 
Leaders with long tenures should be reluctant to sanction change. There are four main reasons for this. First, they should possess wellestablished mental models of priorities, options, and causal relations, prompting them to express confidence in existing strategic, structural, and human arrangements in their organizations. Second, the creation of refined information routines and the cultivation of trusted sources of information familiar with leaders' preferences should encourage these leaders to stay the course. Third, long-tenured leaders' relative mastery of the job should foster disinterest in organizational experimentation. Fourth, these leaders have a stake in the status quo and possess the power to preserve it (Bantel \& Jackson, 1989; Boeker, 1997; Finkelstein \& Hambrick, 1996). Accordingly, there should be a negative relationship between the length of presidential tenure and university retrenchment rates: As presidential tenure increases, rates of adoption of early faculty retirement plans should decrease. But since presidential tenure and age often are intercorrelated (Bantel \& Jackson 1989), this hypothesis can be tested rigorously only if the causal effects of these presidential demographics are disentangled. Therefore, I also examine presidential age, hypothesizing that older presidents' confidence in the status quo will lead them to retrench at lower rates than their younger counterparts (on this general logic, see Bantel \& Jackson, 1989; Hambrick \& Mason, 1984).

Leaders' functional backgrounds should affect how organizational problems and solutions are viewed because leaders increasingly become socialized with the style of thinking and acting appropriate for a functional area as they spend time and achieve successes in that area. So leaders in different functions should have different experiences, cognitive models, and values, prompting them to perceive and to solve problems differently (Bantel \& Jackson, 1989; Finkelstein \& Hambrick, 1996; Fligstein, 1990; Hambrick \& Mason, 1984). Are the academic backgrounds of university presidents a cause of retrenchment? Hardy (1996) discusses the rise of a managerial ethos advocating a business or an economic approach to university administration, which encourages administrators to enhance efficiency through retrenchment and through other means - for example, program evaluation and strategic planning — often linked to retrenchment. Presidents with business or economics 
expertise should be more likely than others to embrace managerialism. Indeed, they especially should have been exposed to the principles of rational efficient management during their university careers. Accordingly, these presidents should view retrenchment as a viable solution to the problems facing their institutions. Fewer managerialists should be found among presidents with different expertise, who thus should be less apt to see retrenchment as a solution to existing problems. I hypothesize that presidents lacking business or economics backgrounds should implement faculty retrenchment (early retirement) plans at lower rates than those with these backgrounds.

Most presidential candidates move from university to university, rising up the job ladder. Consequently, outside leadership succession is far more common than inside succession in higher education (Finkelstein \& Hambrick, 1996). Inside and outside successors should have different dispositions and should face different constraints and opportunities. Insiders tend to be committed to the status quo and thus tend to be reticent to pursue new courses of action. They also tend to be constrained interpersonally and socially due to their long-standing ties to internal personnel, inhibiting them from making personnel changes. Compared to their counterparts, outsiders have low attachments to the existing regime and thus are more open to change. They also are unencumbered interpersonally and socially due to their weak ties to organizational personnel, freeing them to make changes (Finkelstein \& Hambrick, 1996; Hambrick \& Mason, 1984). Applying this information to the context of university retrenchment, I expect that inside presidential successors will adopt early faculty retirement schemes at lower rates than outside successors.

Social change can occur as some members of a social network disseminate information about a practice's ability to solve a problem to others in the network through direct interactions. This social activity allows the others to learn about the practice, to form beliefs about its efficacy and general applicability, and then to adopt it. Focusing on corporate boards of directors, the idea is that exposure to an organizational practice through board membership leads directors to learn about it, to define it as normatively appropriate, and finally to adopt it in their organizations (Davis 1991; Haunschild 1993). I argue that, since retrenchment (including early 
retirement) programs have been common among Canadian firms over the past decade (see the special 1998 issue of Canadian Journal of Administrative Sciences), university presidents sitting on corporate boards have possessed ample information on the potential ability of retrenchment to solve resource (financial) problems. Indeed, corporate leaders not only have supplied presidents with such information, but also have exhorted them to save costs through retrenchment (Useem, 1993). In contrast, lacking the relevant face-to-face interactions, information exchanges, and cognitive transformations experienced by presidents with seats on corporate boards, those without seats should be less likely to perceive retrenchment as a viable problem-solving strategy. If so, then presidential nonmembership on corporate boards and retrenchment will vary negatively: Presidents without board membership will adopt early faculty retirement programs at lower rates than those with board membership.

There is scant theory and research on the relationship between organizational leaders' gender and organizational change because nearly all of these leaders are men (Finkelstein \& Hambrick, 1996). This reality raises the question: How similar are male and female leaders? Studies of corporate managers in general make two relevant comparisons. The one involving women managers and nonmanagers shows that the managers are more achieving, more production-oriented, and more apt to view themselves as having managerial and male characteristics. The other comparison reveals that women and men managers perceive themselves as possessing similar traits and styles (Billing \& Alvesson, 1994; Harriman, 1996; Wacjman, 1998). Although these studies suggest that female and male managers are similar, others report that women must stand out from men in order to secure and to retain high-level posts (Kay \& Hagan, 1998). Their distinctiveness can be demonstrated by having a history of being the first in a new position, by spurring organizational changes, by taking major risks and succeeding, and by other means (Kanter, 1977; Kay \& Hagan, 1998). Since female presidents occupy a nontraditional (leadership) position, and since they thus have good reason to feel pressed to initiate changes and to take risks, their experiences and cognitive models may well lead them to be more likely retrenchers than their male counterparts. Accordingly, I hypothesize that the gender 
of university presidents (male) and retrenchment will vary negatively: Male presidents will adopt early faculty retirement plans at lower rates than female presidents.

\section{Controls}

In order to conclude that university presidents matter, I should show that their attributes affect retrenchment above and beyond the influence of other relevant factors. Therefore I analyze seven statistical controls, two of which are central to resource dependence theory (Benson, 1975; Pfeffer \& Salancik, 1978). Ontario universities depend primarily on the provincial government for their operating expenses (Council of Ontario Universities, 1989-1998), giving the government the power to push them to cut expenses substantially (Ford, 1994; "Making the transition," 1992). Since more than $80 \%$ of university expenditures are on salaries and benefits (Hardy, 1996), universities have responded to the government by cutting faculty expenditures, especially through early faculty retirements ("Making the transition," 1992; Peters, 1995). Recognizing that financial dependence on the government varies across universities, I expect that more dependent universities should retrench at higher rates than less dependent ones. The government also could use a "manipulative" strategy (Benson, 1975) - cuts in operating grants - to speed the spread of early faculty retirement packages. In fact, the universities experienced cuts in real operating grants per student during the $1990 \mathrm{~s}$ ("COU calls," 1991; Gwyn, 1996; "Ontario goes ahead," 1997; Russell, 1998) and many link them to faculty retrenchment (Gwyn, 1996), suggesting that universities with large cuts should retrench at higher rates than those with smaller cuts.

Tests of the diametric forces model of university restructuring show that financial stress causes universities to add business programs, and that the effects of these additions include increased student enrollments and operating margins (Zajac \& Kraatz, 1993). Since this situation suggests that business schools are valuable revenue generators for universities, I hypothesize that institutions with business schools should adopt early faculty retirement plans at lower rates than institutions lacking them. The diametric forces model recognizes that older universities may 
change easily. First, they should have established ties with such powerful outsiders as government officials who provide them with resources that stimulate change (e.g., information revealing the government's serious interest in cost-cutting). Second, they should possess considerable managerial experience and extensive functional structures, which encourage change. University age may influence retrenchment, in particular, because it serves as a proxy for other influences. For one thing, older universities may be more research-oriented than younger ones, making them less sensitive to the possible negative effects of retrenchment on teaching and faculty-student relationships. For another, older institutions may have a larger percentage of older and thus costlier faculty than younger institutions, giving them greater potential financial savings from the adoption of retrenchment plans. This material indicates that age dependence in the adoption of retrenchment plans should be positive.

For methodological reasons, it is important to analyze an organization's complete history of change by taking into account repetitive momentum (Miller \& Frieson, 1980). The idea is that the social legitimacy of a particular change rises each time an organization makes the change, and that the gains in legitimacy increase the likelihood that it will be repeated in the future. Some of Ontario's universities adopted cost (faculty) reduction programs before the 1990s, under social conditions distinctly different from the conditions under which these adoptions occurred. So it would be unwise to examine the adoptions of the 1980s and 1990s using a single empirical model (Palmer et al. 1995). Instead, I focus on the critical decade of the 1990 s, when retrenchment programs proliferated. However, since prior adoptions of these programs may affect the adoptions of interest, I evaluate the hypothesis that adoption rates will be higher among universities with prior adoptions than among ones without them. Although this hypothesis implies that organizations that change are unlikely to stop changing, organizations do pass from periods of change into periods of relative stability. To reconcile this fact with the above hypothesis, I reason that organizations seek solutions to problems by referring to their most recently adopted routines (changes). As the time since a routine's adoption increases, it is less likely that an organization will make additional changes in it (Amburgey, 
Kelly, \& Barnett, 1993). According to this dynamic momentum logic, a university that initiated a change in the distant past is less likely than one that recently initiated it to undertake modifications. Therefore, retrenchment rates should decrease with the elapsed time since the last (preobservation period) adoption of this type occurred.

Finally, strategic leadership researchers (Boeker, 1997) often analyze time dependence in order to determine whether the probability that an organization will undergo change varies over time. Specifications for time dependence are advantageous because they ensure that unspecified, time-specific factors will be held constant (Allison, 1985). Although time dependence often is either positive or negative, it can assume more complicated forms (Allison, 1985; Yamaguchi, 1991). But since preliminary modeling revealed that time dependence in the focal dependent variable is positive (i.e., retrenchment rates increase with the passage of time) I expect time-dependence effects to be positive.

\section{METHODS}

\section{Population and Time Frame}

I examine early faculty retirement programs among the population of universities in Ontario $(\mathrm{N}=17)$, excluding the Royal Military College of Canada (RMC). ${ }^{1}$ Focusing on the period from 1989-90 to 1997-98 does not create "censoring" problems (Allison, 1985; Yamaguchi, 1991). Organizations are right-censored when they have not retrenched by 1997-98. But this occurrence poses no problems, since event-history methods handles it effectively. The main problem with left-censoring occurs when organizations disappear through such means as death before the observation period begins. In these cases, nothing is known about the life histories of organizations that are relevant to the event under study. Such left-censoring is absent in this study, since no universities disappeared before the observation period begins.

\section{Measurement}

Faculty Retrenchment. An early retirement program allows faculty members to leave their current employer before they become eligible for 
normal retirement. The dependent variable specifies the academic year during which each of the universities formally decided to adopt such a program. ${ }^{2}$ To obtain information on the dependent variable, I contacted officials in each university's Human Relations or Personnel Office. These officials also offered supplementary details on the retrenchments, such as the number of early faculty retirees and the content of the early retirement agreements, and some provided formal documentation on the retrenchments. I verified the information supplied by the officials through contacts with faculty associations at the universities and/or through examination of published articles on the retrenchments.

Independent Variables. Beginning with the leadership variables, academic background is a dummy variable scored as 1 for presidents lacking business or economics backgrounds and as 0 otherwise. Age and tenure refer to the age of the president and to the number of years $\mathrm{s} / \mathrm{he}$ has held office, respectively. Corporate board experience, gender, and successor type are dummies coded as 1 for presidents lacking seats on corporate boards and as 0 for those with seats, as 1 for male presidents and as 0 for women presidents, and as 1 for inside presidential appointments and as 0 for outside appointments, respectively. All of these data come from Who's Who in Canada and from private communications with the presidents. Turning to the controls, university dependence is the percentage of each university's annual expendable revenues secured through government grants, the data for which can be found in the Council of Ontario Universities' (COU's) Financial Report of Ontario Universities: Volume 1 -Universities. Net revenue decline is the rate of decrease in each university's real net revenues (total revenues minus expenditures) from 1989-90 to 1997-98. Since shifts (particularly declines) in university finances are driven almost exclusively by shifts in government funding, this variable provides information on shifts in government funding of universities over time. I collected the data from the COU's Financial Report of Ontario Universities: Volume 1 Universities. Business school is a dummy scored as 1 for universities with business schools and as 0 otherwise. The data come from the Guide to Business Schools (1998). University age is the total number of years since the establishment of each university. I logged this variable in order 
to normalize its distribution and obtained the data from Cameron (1991). I scored repetitive momentum as unity when a university implemented a retrenchment plan prior to the observation period (from 1989-90 to 1997-98) and as zero otherwise. With respect to dynamic momentum, I constructed a duration "clock" to record the number of years that elapsed since the adoption of an early faculty retirement plan (Amburgey, Kelly, \& Barnett, 1993). The clock's value is 0 until an adoption occurs. If an adoption occurs before 1989-90, then the clock records the elapsed time since this adoption up to the time of adoption in the observation period. So for the right-censored university that never had an adoption, the value of the clock is 0 throughout the observation period. For universities with adoptions during the observation period only, the value of the clock is 0 until these adoptions occur. For universities with adoptions before and during the observation period, the value of the clock is 0 until the preobservation period adoption occurs; the clock then records the passage of time until the observation period adoption occurs. No university combined a pre-observation period adoption with non-adoption during the observation period. Time dependence is a measure of calendar time.

\section{Model}

I modeled the program adoptions using discrete-time event history models (Allison, 1985; Yamaguchi, 1991) ${ }^{3}$ and began by creating a record for each academic year that each university was at risk of retrenching. For each university, I coded the dependent variable as 0 in years in which the event did not occur and as 1 in the year in which it finally did. I coded this variable as 0 for each relevant year when a university never experienced the event; these cases are said to be "censored." I also assigned values of independent variables for each university in each relevant year before pooling the completed records for statistical analysis. I began with the following logistic regression model:

$$
P(t)=a+b_{k} x_{k}+b_{k} x_{k}(t)
$$


where: $\mathrm{P}(\mathrm{t})$ is the hazard or transition rate, the probability of retrenching at time $t$ for universities at risk of undergoing retrenchment; $a$ is the intercept; $x_{k}$ is a vector of time-invariant independent variables (e.g., repetitive momentum); and $x_{k}(t)$ is a vector of time-varying independent variables (e.g., university age). Two of these variables - university dependence and net revenue decline - are lagged to guard against simultaneity problems. The dependent variable $\mathrm{P}(\mathrm{t})$ is a linear function of the independent variables, whose coefficients, $b_{k}$ and $b_{k}(t)$, are estimated using the method of maximum likelihood. These coefficients are similar to unstandardized regression coefficients in that they depend on the metric of each independent variable: The coefficients $b_{k}$ and $b_{k}(t)$ specify the change in the logit (log-odds) for each one-unit increase in $x_{k}$ and $x_{k}(t)$, respectively. To avoid computational and interpretative problems, I reformulated equation (1) by calculating the logit transformation of $\mathrm{P}(\mathrm{t})$ and used this model in the empirical analyses:

$\log P(t) / 1-P(t)=a+b_{k} x_{k}+b_{k} x v(t)$

\section{CAUSES OF RETRENCHMENT}

\section{Baseline Model}

The annual rates of adoption of early faculty retirement packages are plotted in Figure 1, raising the question: Why do these rates vary over time? I answer this question by beginning with a brief review of a baseline model containing statistical controls that explain $50 \%$ of the variation in the adoption rates (see Table 2 ). ${ }^{4}$ These rates are related positively to five of the controls - net revenue decline, university dependence, university age, dynamic momentum, and time dependence - and are related negatively to two of them - presence of a business school and repetitive momentum. As expected, retrenchers suffer large governmentdriven reductions in net revenues, secure a large percentage of their operating revenues from the provincial government, are older institutions, and do not possess business schools. Also, the rate of adoption of early faculty retirement plans increases with the passage of time. 
Figure 1

Annual faculty retrenchment rates among Ontario universities, 1989-1997

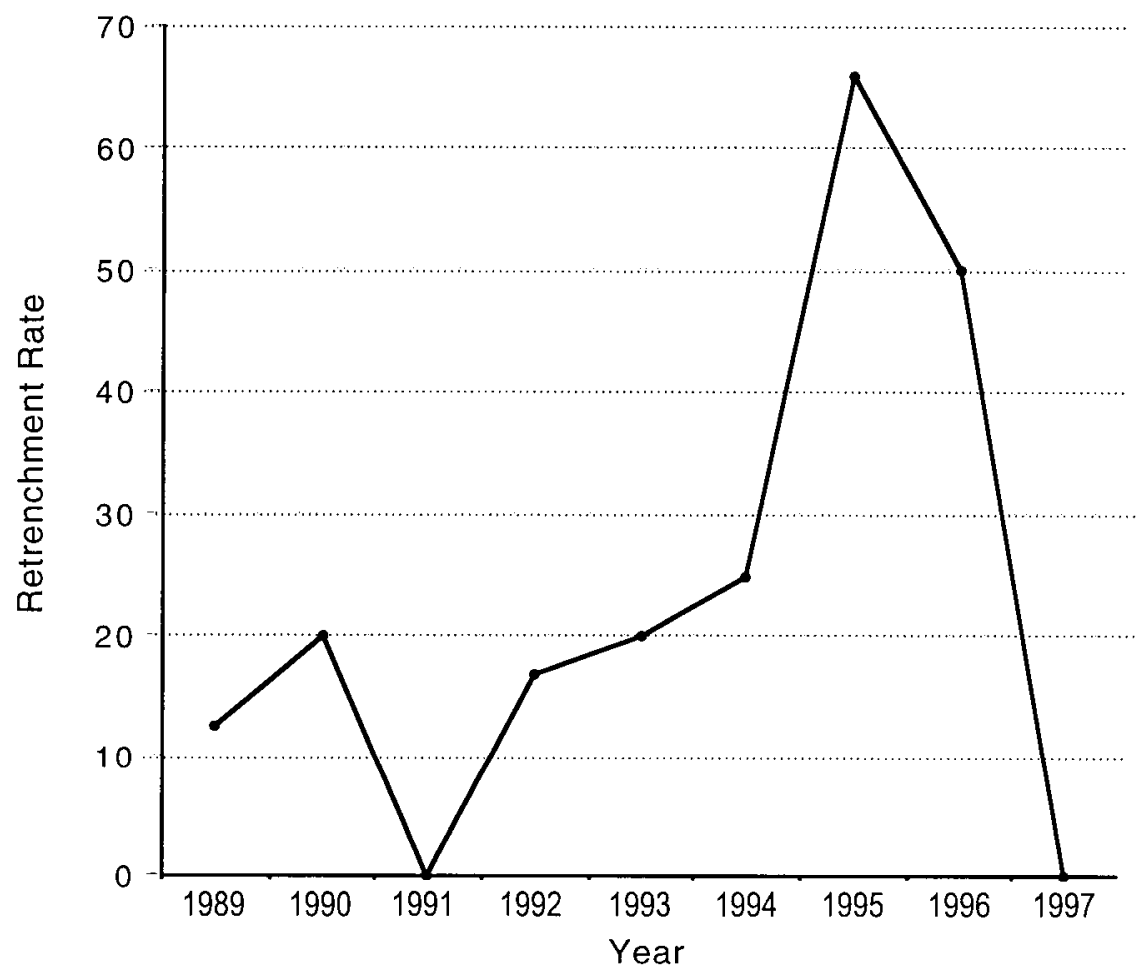


Table 2

\section{Adoption of early faculty retirement plans among Ontario universities, 1989-90 to 1997-98}

\begin{tabular}{|c|c|c|}
\hline Model & 1 & 2 \\
\hline $\begin{array}{l}\text { Presidential Characteristics: } \\
\text { Tenure }\end{array}$ & & $\begin{array}{r}-.117 \\
(.282)\end{array}$ \\
\hline$\overline{\text { Age }}$ & & $\begin{array}{r}.254 \\
(.210)\end{array}$ \\
\hline $\begin{array}{l}\text { Academic Background } \\
(1=\text { non-business/non-economics })\end{array}$ & & $\begin{array}{c}-4.20 \mathrm{~b} \\
(2.19) \\
\end{array}$ \\
\hline Successor Type ( $1=$ insider $)$ & & $\begin{array}{l}3.57^{\mathrm{a}} \\
(2.90) \\
\end{array}$ \\
\hline Corporate Board Experience $(1=$ no $)$ & & $\begin{array}{l}9.41^{\mathrm{c}} \\
(4.05) \\
\end{array}$ \\
\hline Gender $(1=$ male $)$ & & $\begin{array}{r}-10.94^{b} \\
(5.38) \\
\end{array}$ \\
\hline $\begin{array}{l}\text { Controls: } \\
\text { University Dependence }\end{array}$ & $\begin{array}{l}.184^{\mathrm{b}} \\
(.093)\end{array}$ & $\begin{array}{r}.751^{\mathrm{c}} \\
(.304)\end{array}$ \\
\hline Net Revenue Decline & $\begin{array}{l}3.20^{\mathrm{c}} \\
(1.21)\end{array}$ & $\begin{array}{l}9.50^{\mathrm{c}} \\
(3.85)\end{array}$ \\
\hline Business School (1=yes) & $\begin{array}{l}1.94^{\mathrm{a}} \\
(1.49)\end{array}$ & $\begin{array}{c}-7.39 \mathrm{~b} \\
(4.55)\end{array}$ \\
\hline University Age & $\begin{array}{l}1.87^{\mathrm{c}} \\
(.832)\end{array}$ & $\begin{array}{l}4.77^{\mathrm{b}} \\
(2.39)\end{array}$ \\
\hline Repetitive Momentum & $\begin{array}{c}-8.03^{c} \\
(2.96) \\
\end{array}$ & $\begin{array}{c}-21.23^{c} \\
(8.86) \\
\end{array}$ \\
\hline Dynamic Momentum & $\begin{array}{l}.641^{\mathrm{c}} \\
(.255)\end{array}$ & $\begin{array}{l}2.07^{\mathrm{C}} \\
(.853) \\
\end{array}$ \\
\hline Time Dependence & $\begin{array}{l}.539 \mathrm{~b} \\
(.260)\end{array}$ & $\begin{array}{l}2.70^{\mathrm{c}} \\
(1.15)\end{array}$ \\
\hline $\begin{array}{l}\text { Adjusted R } \\
-2 \text { Log Likelihood }\end{array}$ & 48.64 & 26.61 \\
\hline${ }^{a} p<.10 \quad b_{p}<.05 \quad c_{p}<.01$ & (one-tailed tests) & \\
\hline
\end{tabular}

Notes: University-years $=77$; standard errors are in parentheses. 
A university that retrenched before the observation period should have done so again during it, having become familiar with this change (repetitive momentum). But as the time since the university's initial retrenchment passed, the change should have become less relevant to its search for solutions to new problems; as a result, modifications in the change increasingly should have declined (dynamic momentum). So why do the results indicate that universities with retrenchment experience have lower retrenchment rates than others, and that retrenchment rates increase as the time since the initial retrenchment increases? There should be no reason to modify an initial change as long as it solves a problem adequately; indeed, modifications would be unnecessary and could even be counterproductive. Retrenchment rates thus are lower among universities with retrenchment histories than among others because the former universities matched a solution - retrenchment with a set of problems - government pressure to economize, for example - before the onset of the observation period. And it is only when social conditions evolve over time that the nature and/or severity of an organizational problem should change, motivating an organization to search for a new solution to the current problem. Hence, the political economy in which Ontario universities operated began to change in the early 1990s, prompting universities with old retrenchment policies illsuited for current conditions to introduce new ones.

\section{Leadership Model}

To determine whether presidential backgrounds contribute toward explaining the adoption rates, above and beyond the explanation offered by the controls, I used the Likelihood-Ratio Chi-Square statistic to test the null hypothesis that adding the background factors (see model 2 in Table 2) to model 1 has no effect on the model's fit (Allison, 1984). ${ }^{5}$ Since this statistic reveals that the fit improves when these factors are taken into account $(\mathrm{p}<.01)$, I reject the null hypothesis and conclude that presidents matter in the analysis of retrenchment (early faculty retirement) plans among Ontario universities from 1989-90 to 1997-98. Indeed, the addition of the background factors boosts the variation explained by about $27 \%$, bringing the overall variation explained to 


\section{A. Budros}

nearly $77 \%$. While the results for the controls are unchanged in model 2 , four of the six background factors are significant statistically: The signs attached to the coefficients for corporate board experience, academic background, and presidential gender are negative and the sign attached to the coefficient for successor type is positive (this factor is marginally significant at $\mathrm{p}=.10$ ). Before discussing these results, I should note that my conclusion that university presidents influence retrenchment is not based on direct observation of presidential behavior. Instead, it is based on the empirical evidence (statistics) linking presidential backgrounds and retrenchment, and on the theoretical logic underlying these links.

As an industrial ethos has penetrated higher education in Canada, administrators have introduced managerial techniques into their universities. Managerialism has four key features. First is strategic planning, a set of analytical techniques used to evaluate university strengths and weaknesses in the face of environmental constraints and opportunities, with the evaluation followed by the formulation and implementation of a rational administrative plan. Second is decisive action, whereby weak areas of a university are eliminated and strong areas receive extra resources. Third is the central role played by the president in strategic decision-making. Fourth is the assumption that rational analysis produces "objective" information that unambiguously discloses optimal strategies. Insofar as it advocates systematic program evaluation, objective resource allocation, and directive leadership to improve performance, managerialism has been associated with retrenchment (Hardy, 1996). The findings on presidential board experience and academic backgrounds add insight into the association between managerialism and retrenchment, suggesting that presidents with relatively weak managerial orientations - those without corporate board experience, such as Nipissing's David Marshall, or those without academic experience in business or economics, such as York's Harry Arthurs - gain less exposure to managerial techniques and ideology than presidents with stronger managerial orientations - those possessing corporate board experience, such as Terrence White (a director of Labatt's Brewery and author of a book on directors in Canadian corporations) who led Brock and Calgary, or those possessing academic backgrounds in business or economics, 
such as Wilfrid Laurier's John Weir. And as a result, the former adopt early faculty retirement schemes at lower rates than the latter.

Retrenchment rates are lower among male than among female presidents, inviting further discussion of the retrenching tendencies of the latter. Some evidence indicates that women must demonstrate special talents - for example, by spearheading change or by taking risks - in order to occupy leadership positions (Kanter, 1977; Kay \& Hagan, 1998). This finding adds to this evidence, the special talents being reflected in the tendency of female presidents to preside over university adoptions of early faculty retirement programs. As an illustration of this tendency, York introduced a Special Early Retirement Program (SERP) to faculty while Susan Mann was the university's president in the earlyto-mid 1990s. The program initially was offered to about 350 faculty members, 40 of whom enrolled in it. The program later was offered to about 405 faculty members, 20 of whom accepted the offer. The objective was to allow eligible faculty members to retire early while allowing the university to restructure its operations and to reduce permanently its base budget during the mid-to-later 1990s. Recognizing the political and financial realities facing all Ontario universities, Mann stated: "Across the system, I think you will have fewer professors, larger classes and a lot more experimentation with technology" (Duffy, 1995).

Although organizational change generally occurs when a leader has been recruited from outside an organization (Finkelstein \& Hambrick, 1996), these findings show that it tends to occur when a leader has been promoted from within an organization. This situation can be explained by recognizing that, while the literature overwhelmingly addresses leadership succession in corporations with many thousands of employees (Birnbaum, 1989a; Finkelstein \& Hambrick, 1996; Keast, 1996), this study examines it in universities with hundreds of employees (faculty members). The demographic, structural, and cultural differences between these two contexts suggest that inside university successors should have greater opportunities than their corporate counterparts to cultivate strong professional and personal ties with many members of their organizations. Indeed, before taking office, inside university successors are able to serve on a wide range of departmental, interdepartmental, and university-wide 
committees, enabling them to develop rich, extensive social networks. These findings indicate that such inside university successors as Ottawa's Marcel Hamelin and Windsor's Ronald Ianni take advantage of the bonds of trust and confidence they have nurtured with their brethren in endorsing early retirement plans aimed at reducing faculty employment levels.

\section{CONCLUSION}

Since the wealth of studies stating that universities are not molded by their presidents (Birnbaum, 1989b; Cohen \& March, 1974; Dennison \& Gallagher, 1986; Sibley, 1993) typically are atheoretical (Birnbaum, 1989a) and perceptual (Levin, 1992) in nature, additional appraisals of presidential power are required before definitive conclusions on this issue can be drawn. To this end, I have used strategic leadership theory (Bantel \& Jackson, 1989; Boeker, 1997; Finkelstein \& Hambrick, 1996; Hambrick \& Mason, 1984) to determine whether observable experiences of presidents influenced the adoption of retrenchment (early faculty retirement) schemes among Ontario universities from 1989-90 to 1997-98. These adoptions have swept across these universities during the past decade (Gwyn, 1996; "Making the transition," 1992; Melchers, 1998; Peters, 1995; "Summary," 1993) and evidence indicates that they have affected academic conditions adversely ("Making large classes work," 1992; McGaw, 1993; "Tips and techniques." 1991). The adoptions thus are important, representing a key structural change among higher educational institutions that combines potential financial benefits and educational costs.

The results show that who presidents are and what they do shape institutional change. Those who lack seats on corporate boards, who have non-business or non-economics backgrounds, who are male, and who are external hires introduce early faculty retirement plans at lower rates than those who serve on corporate boards, who have business or economics backgrounds, who are female, and who are internal hires. These results are impressive because the literature attributes the adoption of these plans to intractable pressures, especially public ambivalence about university operations and consequent government cuts in university funding 
(Gumport, 1993; Lorimer, 1993; Melchers, 1998; Neumann, 1995; Peters, 1995; Slaughter, 1993; "The thorny problem," 1995). Therefore, I should have discovered that the adoptions cannot be traced to presidents, but this did not happen. The results portray presidents neither as impotent reactors to hostile environments nor as heroic masters of their environments, but as individuals with personal and professional experiences affecting how they handle information and make decisions. Consequently, some can have a greater likelihood of making a specific change than others. This consequence means that presidents can be seen as exercising circumscribed agency, struggling to make a difference and succeeding even under inhospitable circumstances.

This research also advances strategic leadership theory, which has focused on the link between three characteristics reflective of leaders' observable experiences - tenure, functional background, and formal education - and outcomes among corporations. Strategic leadership theorists (Finkelstein \& Hambrick, 1996) acknowledge the need to broaden the set of leader experiences and populations under investigation and, in response, I have combined conventional and unconventional measures of leader experiences in examining a specific outcome (retrenchment) among universities. Of course, extant theoretical contributions of this research should not go unnoticed. For example, interest in the link between social structure and economic action has generated a literature showing that embeddedness in social networks affects corporate outcomes (Uzzi, 1996). Much of this literature reveals the impact that embeddedness in intercorporate networks, especially a corporate actor's membership on corporate boards of directors, has on corporate change. The assumption is that directors gather information on the kind of practices other directors use to solve a problem. The information shapes the cognitive map and values of a director lacking a preferred practice, motivating the director to adopt it in her/his corporation (Davis, 1991; Haunschild, 1993; Palmer at al., 1995). This research contributes to this literature by demonstrating that embeddedness in interindustry networks - a university president's membership on a corporate board - influences retrenchment. The evidence suggests that presidents with board experience learn about this practice or, more generally, about the 
value of efficient personnel policies from corporate directors and apply what they have learned by retrenching their universities. In contrast, those lacking board experience have less exposure to retrenchment ideology and procedures, leading them to avoid retrenchment. Since network processes may underlie the relationship between other leader attributes - for example, successor type (insider/outsider) - and retrenchment, we need to devote additional theoretical and empirical attention to structural embeddedness in future retrenchment research. This sort of theoretical cross-fertilization should facilitate our search for an adequate understanding of retrenchment and, more generally, of the interrelationships among leaders, their organizations, and organizational outcomes.

\section{Notes}

1 The RMC specializes in educating and training students for careers as commissioned officers in the Canadian Forces and offers a limited number of academic programs (Directory of Canadian Universities). Also, its operation is affected by factors that are irrelevant to the other universities. Since the RMC is unique, in terms of its academic orientation and in terms of the factors that might induce it to retrench, it makes sense to omit the institution from the formal models.

2 Although universities repeatedly could have adopted early faculty retirement programs from 1989-90 to 1997-98, I investigate their initial adoptions during these years for three reasons. One is that subsequent adoptions have been uncommon and typically have involved extensions of initial programs or minor program changes. Another is that initial adoptions should entail decision-making that carries greater risk and uncertainty than that involved in subsequent adoptions, suggesting that the causes of initial and subsequent adoptions may vary and thus that these events should be modeled separately. The third reason for investigating why universities adopt early faculty retirement programs for the first time is that empirical analysis of repeated adoptions requires assumptions (e.g., a modulated renewal process) that are violated easily (on other statistical issues, see Allison, 1984; Yamaguchi, 1991). 
3 The use of this discrete-time event history model is appropriate in this context, for two key reasons. First, this model should be used when variables are measured in relatively large units of time, such as years, and both the independent and dependent variables in this study are measured in years. Second, occasionally retrenchments occur for a substantial number of universities at the same time and, unlike "continuous-time" event history models, discrete-time models readily handle this situation. Plus, discrete-time models nearly always generate findings that closely resemble those generated by continuous-time models (on these issues, see Allison, 1985; Yamaguchi, 1991).

4 Let me make three points about the model in Table 2. First, as is standard practice (Blalock, 1979; Steffensmeier \& Demuth, 2000), I use tests of statistical inference even though I am investigating a population (all Ontario universities) rather than a sample. These tests thus do not apply in the conventional sense of assessing error in making inferences to the population from which the sample was drawn. Instead, they are used to make inferences about the causal processes generating the population data, reflecting an interest in theoretical explanation or in why any given relationship has been reported. In this context, a statistically significant relationship reflects differences between subpopulations - the probability of retrenchment among old versus younger universities, for example - so substantial that the relationship is viewed as occurring not due to chance but due to causal processes described through theoretical logic (Blalock, 1979). Second, in this discrete-time event history analysis, the number of cases is specified in terms of university-years. The number of years each university remains in the risk set is calculated and these figures then are summed up (Allison, 1985; Yamaguchi, 1991). The relatively small number of cases in this study $(\mathrm{N}=77)$ means that the standard errors likely are inflated, artificially increasing significance levels. Consequently, I follow the conventional practice of using $\mathrm{p}<.10$ as the baseline significance level (Bradshaw, 1987; Devine, 1983). Third, supplementary diagnostics indicate that multicollinearity (the largest Variance Inflation Factor or VIF is 7.6, well below the problematical value of 10 , and the largest Condition Index is 6.6, nowhere near the problematical value of 20) poses no problems in these analyses.

5 The leadership variables also do not possess multicollinearity problems (the largest VIF is 3.6 and the largest Condition Index is under 3.0). 


\section{References}

Allison, P. (1985). Event history analysis. Thousand Oaks, CA: Sage.

Amburgey, T., Dawn, K., \& Barnett, W. (1993). Resetting the clock: The dynamics of organizational change and failure. Administrative Science Quarterly, 38, 51-73.

Baldridge, J., Curtis, D., Ecker, G., \& Riley, G. (1980). Policy making and effective leadership. San Francisco, CA: Jossey-Bass.

Bantel, K. \& Jackson, S. (1989). Top management and innovations in banking: Does the composition of the top team make a difference? Strategic Management Journal, 10, 107-124.

Benson, K. (1975). The interorganizational network as a political economy. Administrative Science Quarterly, 20, 228-249.

Billing, Y. \& Alvesson, M. (1994). Gender, managers, and organizations. Berlin: Walter de Gruyter.

Birnbaum, R. (1988). How colleges work: The cybernetics of academic organization and leadership. San Francisco, CA: Jossey-Bass.

Birnbaum, R. (1989a). The implicit leadership theories of college and university presidents. Review of Higher Education, 12, 125-136.

Birnbaum, R. (1989b). Presidential succession and institutional functioning in higher education. Journal of Higher Education, 60, 123-135.

Blalock, H. (1979). Social statistics. New York, NY: McGraw-Hill.

Blau, P. (1973). The organization of academic work. New York, NY: John Wiley \& Sons.

Boeker, W. (1997). Strategic change: The influence of managerial characteristics and organizational growth. Academy of Management Journal, $40,152-170$.

Bradshaw, Y. (1987). Urbanization and underdevelopment: A global study of modernization, urban bias, and economic dependency. American Sociological Review, 52, 224-239.

Cameron, D. (1991). More than an academic question: Universities, government, and public policy in Canada. Halifax, NS: Institute for Research on Public Policy.

Chabotar, K. \& Honan, J. (1990). Coping with retrenchment: Strategies and tactics. Change, 22, 28-34.

Chaffee, E. (1984). Successful strategic management in small private colleges. Journal of Higher Education, 55, 212-241.

Clark, B. (1973). The organizational saga in higher education. Administrative Science Quarterly, 17, 178-184. 
Cohen, M. \& March, J. (1974). Leadership and ambiguity: The American college president. New York, NY: McGraw-Hill.

Corson, J. (1960, 1975). Governance of colleges and universities. New York, NY: McGraw-Hill.

COU calls for new funding initiatives. (1991, May). University Affairs, 8.

Council of Ontario Universities. (1989-1997). Financial report of Ontario universities, Vol. 1 - Universities. Toronto, $\mathrm{ON}$ : Council of Ontario Universities.

Cuts hurt our university libraries. (2000, June). CAUT Bulletin, 1.

Davis, G. (1991). Agents without principles? The spread of the poison pill through the intercorporate network. Administrative Science Quarterly, 36, 583-613.

Demerath, N., Stephans, R., \& Taylor, R. (1967). Power, presidents, and professors. New York, NY: Basic.

Dennison, J. \& Gallagher, P. (1986). Canada's community colleges: A critical Analysis. Vancouver, BC: University of British Columbia Press.

Devine, J. (1983). Fiscal policy and class income inequality. American Sociological Review, 48, 606-622.

Duffy, A. (1995, December 24). Three universities plan 20\% hike. Toronto Star, p. A7.

Finkelstein, S. \& Hambrick, D. (1996). Strategic leadership: Top executives and their effects on organizations. Minneapolis/St. Paul, MN: West Publishing Company.

Fisher, J. (1984). Power of the presidency. New York, NY: Macmillan.

Fligstein, N. (1990). The transformation of corporate control. Cambridge, MA: Harvard University Press.

Ford, C. (1994, April). Budget impact on universities still unclear. University Affairs, 17.

Gates, G. (1997). Isomorphism, homogeneity, and rationalism in University retrenchment. Review of Higher Education, 20, 253-275.

Gilley, J., Fulmer, K., \& Reithlingshoefer, S. (1986). Searching for academic excellence: Twenty colleges and universities on the move and their leaders. New York, NY: Macmillan.

Glenny, L., Shea, S., Ruyle, J. \& Freschi, K. (1976). Presidents confront reality. San Francisco, CA: Jossey-Bass.

Gray, H. (1998). On the history of giants. In W. Bowan \& H. Shapiro (Eds.), Universities and their leadership (pp. 101-118). Princeton, MA: Princeton University Press.

Gross, E. \& Grambsch, P. (1968). University goals and academic power. Washington, DC: American Council on Education. 
Gross, E. \& Grambsch, P. (1971). Changes in university organization, 1964-1971. New York, NY: McGraw-Hill.

Gumport, P. (1993). The contested terrain of academic program reduction. Journal of Higher Education, 64, 283-311.

Gwyn, R. (1996, January). How will laid-off workers buy their employers' products? CAUT Bulletin, 5 .

Hambrick, D. \& Mason, P. (1984). Upper echelons: The organization as a reflection of its top managers. Academy of Management Review, 9, 193-206.

Hardy, C. (1996). The politics of collegiality: Retrenchment strategies in Canadian universities. Montreal, QC: McGill-Queen's University Press.

Harriman, A. (1996). Women/men/management. Westport, CT: Praeger.

Jencks, C. \& Reisman, D. (1968). The academic revolution. Chicago, IL: University of Chicago Press.

Haunschild, P. (1993). Interorganizational imitation: The impact of interlocks on corporate acquisition activity. Administrative Science Quarterly, $38,564-592$.

Hodgkinson, H. (1971). The next decade. In H. Hodgkinson \& L. Meeth (Eds.), Power and authority (ch. 9). San Francisco,CA: Jossey-Bass.

Kanter, R. (1977). Men and women of the corporation. New York, NY: Basic.

Kay, F. \& Hagan, J. (1998). Raising the bar: The gender stratification of law-firm capital. American Sociological Review, 63, 728-743.

Keast, D. (1996). Values in the decision making of CEOs in public colleges. Canadian Journal of Higher Education, 26, 1-34.

Kerr, C. (1963). The uses of the university. New York, NY: Harper.

Kerr, C. \& Gade, M. (1986). The many lives of academic presidents: Time, place, and character. Washington, DC: Association of Governing Boards of Universities and Colleges.

Levin, J. (1992). The paradox of the presidency: The difference a president makes in institutional functioning at three community colleges. Canadian Journal of Higher Education, 12, 28-45.

Levin, J. (1995). The challenge of leadership. In J. Dennison (Ed.), Challenge and opportunity: Canada's community colleges at the crossroads (ch. 2). Vancouver, BC: UBC Press.

Lorimer, J. (1993, March). Financial exigency. CAUT Bulletin, 4.

Making large classes work. (1992, July). University Affairs, 17.

Making the transition. (1992, November). University Affairs, 15.

McGaw, R. (1993, April). Funding restraints aggravate workload woes. CAUT Bulletin, 4. 
McGrath, E. (1971). Who should have the power? In H. Hodgkinson \& L. Meeth (Eds.), Power and authority (ch. 12). San Francisco, CA: Jossey-Bass.

Melchers, R. (1998, Spring). Ontario universities. OCUFA Forum, 10.

Miller, D. \& Frieson, P. (1980). Momentum and revolution in organizational adaptation. Academy of Management Journal, 23, 591-614.

Mortimer, K. \& McConnell, T. (1978). Sharing authority effectively: Participation, interaction, and discretion. San Francisco, CA: Jossey-Bass.

Neumann, A. (1989). Strategic leadership: The changing orientations of college presidents. Review of Higher Education, 12, 137-151.

Neumann, A. (1995). On the making of good times and bad times: The social construction of resource stress. Journal of Higher Education, 66, 3-31.

Neumann, A. \& Bensimon, E. (1990). Constructing the presidency: College presidents' images of their leadership roles, a comparative study. Journal of Higher Education, 61, 678-701.

Ontario goes ahead with 1997-98 funding freeze. (1997, January). CAUT Bulletin, 9.

Our aging professoriate. (1989, May). CAUT Bulletin, 8.

Palmer, D., Barber, B., Zhou, X., \& Soysal, Y. (1995). The friendly and predatory acquisition of large U.S. corporations in the 1960s: The other contested terrain. American Sociological Review, 60, 469-499.

Peters, D. (1995, May). Cutbacks and retrenchment. CAUT Bulletin, 2.

Pfeffer, J. \& Salancik, G. (1978). The external control of organizations: A resource dependence perspective. New York, NY: Harper \& Row.

Reisman, D. (1970). Predicaments in the career of the college president. In C. Kruytbosch \& S. Messinger (Eds.), The state of the university: Authority and change (pp. 73-86). Beverly Hills, CA: Sage.

Renner, K. (1986). Career alternatives: Providing a cafeteria of choices through career alternative dollars. Research in Higher Education, 25, 227-244.

Renner, K. (1988). Replacing retrenchment with dynamism through a program of career alternatives. Canadian Psychology, 29, 342-54.

Rhoades, G. (1998). Managed professionals: Unionized faculty and restructuring academic labor. Albany, NY: State University of New York Press.

Russell, M. (1998, October). University revenue falls in 1996-97. CAUT Bulletin, 6.

Schuster, J., Smith, D., Korak, K., \& Yamada, M. (1994). Strategic governance: How to make big decisions better. Phoenix, AZ: Oryx.

Shapiro, H. (1998). University presidents - Then and now. In W. Bowan \& H. Shapiro (Eds.), Universities and their leadership (pp. 65-100). Princeton, MA: Princeton University Press. 
Sibley, W. (1993). The university in the 1990s: Crisis or predicament? Canadian Journal of Higher Education, 23, 114-132.

Skolnik, M. (1986). If the cut is so deep, where is the blood? Problems in research on the effects of financial restraint. Review of Higher Education, 9 , 435-455.

Skolnik, M. (1987). The shell game called system rationalization: The politics and economics of retrenchment in the Ontario university system. Higher Education, 16, 155-171.

Skolnik, M. \& Rowan, N. (1984). Please, sir, I want some more: Canadian universities and financial restraint. Toronto, ON: OISE Press.

Slaughter, S. (1993). Retrenchment in the 1980s: The politics of prestige and gender. Journal of Higher Education, 64, 250-282.

Social contract. (1993, September). CAUT Bulletin, 1 .

Steffensmeier, D. \& Demuth, S. (2000). Ethnicity and sentencing outcomes in U.S. federal courts: Who is punished more harshly? American Sociological Review, 65, 705-729.

Stoke, H. (1959). The American college president. New York, NY: Harper.

Summary of Ontario's social contract agreements. (1993, December). CAUT Bulletin, 3.

The thorny problem of sessionals. (1990, February). CAUT Bulletin, 11.

Tips and techniques for teaching large classes. (1991, December). University Affairs, 17.

University funding. (1991, July). University Affairs, 9.

Useem, M. (1993). Executive defense. Cambridge, MA: Harvard University Press.

Uzzi, B. (1996). Embeddedness and economic performance: The network effect. American Sociological Review, 61, 674-698.

Vaughan, G. (1986). The community college president. New York, NY: Macmillan.

Wacjman, J. (1998). Managing like a man: Men and women in corporate management. University Park, PA: Pennsylvania State University Press.

Who's Who in Canada (90th ed.). (1999). Toronto, ON: International Press.

Yamaguchi, K. (1991). Event history analysis. Thousand Oaks, CA: Sage.

Zajac, E. \& Kraatz, M. (1993). A diametric forces model of strategic change: Assessing the antecedents and consequences of restructuring in the higher education industry. Strategic Management Journal, 14, 81-102. 